\title{
Transmission of Grapevine Leafroll Viruses by Planococcus ficus (Hemiptera: Pseudococcidae) and Ceroplastes rusci (Hemiptera: Coccidae)
}

\author{
N. Mahfoudhi, Laboratoire de Protection des Végétaux, Institut National de la Recherche Agronomique de Tunisie, \\ Rue Hedi Karray, 2049 Ariana, Tunisie; M. Digiaro, Istituto Agronomico Mediterraneo, Via Ceglie 9, 70010 Valen- \\ zano Bari, Italy; and M. H. Dhouibi, Laboratoire d'Entomologie, Institut National Agronomique de Tunisie (INAT), \\ Rue Charles Nicolles, 1002 Belvedère, Tunisie
}

\begin{abstract}
Mahfoudhi, N., Digiaro, M., and Dhouibi, M. H. 2009. Transmission of grapevine leafroll viruses by Planococcus ficus (Hemiptera: Pseudococcidae) and Ceroplastes rusci (Hemiptera: Coccidae). Plant Dis. 93:999-1002.

Grapevine leafroll associated virus-3 (GLRaV-3) and Grapevine leafroll associated virus-5 (GLRaV-5), two members of the genus Ampelovirus associated with grapevine leafroll disease, were transmitted by the mealybug Planococcus ficus and the soft scale insect Ceroplastes rusci from infected to healthy vines under experimental conditions. The efficiencies of transmission of GLRaV-3 and GLRaV-5 by P. ficus were 23.3 and $8.3 \%$, respectively, and by $C$. rusci were 3.3 and $1.7 \%$, respectively. Juvenile instars of $P$. ficus were more efficient in transmission of the viruses than adult females. This is the first report of the ability of $C$. rusci to transmit these viruses to grapevines.
\end{abstract}

Leafroll is one of the most important viral diseases occurring in vineyards all over the world (23). In general, leafroll disease does not kill affected vines, but can induce a marked reduction in fruit yield, ranging from 35 to $70 \%$, and a reduction in quality of both wine and table grapes $(17,31)$. Up to now, nine different viruses, all members of the family Closteroviridae, are known to be associated with the disease $(2,14,24)$. Leafroll viruses are restricted to grapevine phloem tissues and are easily transmitted by standard grapevine propagation methods.

A successful approach for the control of leafroll disease in most grapevine growing countries entails the use of certified plant material. Infected vines, in fact, represent the viral foci from which mealybugs and scale insects may acquire and subsequently spread the viruses. Of the viruses associated with leafroll, only Ampelovirus species, Grapevine leafroll associated viruses1, -3, -5, and -9 (GLRaV-1, -3, -5, and -9), have known vectors among mealybugs and scale insects (24). GLRaV-1 is vectored by the scale insects Parthenolecanium corni and Neopulvinaria innumerabilis and by the mealybugs Heliococcus bohemicus and Phenococcus aceris $(12,28)$. GLRaV-3 is transmitted by the mealybugs Planococcus ficus, P. citri, Pseudococcus longispinus, Ps. calceolariae, Ps. viburni, Ps. mariti-

Corresponding author: N. Mahfoudhi

E-mail: nmahfoudhi@yahoo.fr

Accepted for publication 5 May 2009.

doi:10.1094/PDIS-93-10-0999

(C) 2009 The American Phytopathological Society mis, H. bohemicus, Phenococcus aceris, and Ps. comstocki $(7,11,13,25,26,28)$, and by the scale insect Pulvinaria vitis (3). GLRaV-5 and -9 are both transmitted by Ps. longispinus (29).

Natural spread of leafroll disease by mealybugs in vineyards has been reported in many countries $(4,8,16)$. In the presence of GLRaV-3 foci, the spread of leafroll disease can be rapid, as observed in New Zealand (16) and Spain (8). Several field surveys $(5,21,22)$ indicated the occurrence of GLRaV-1, -2, -3, -5, and -9 in Tunisian vineyards, with GLRaV-3 and GLRaV-5 most prevalent in single infections or in mixtures with the other viruses. $P$. citri (Risso) and P. ficus (Signoret) were commonly found in Tunisian vineyards, also in mixed infestations (N. Mahfoudhi and M. H. Dhouibi, unpublished data). These mealybugs are of particular interest for their extensive distribution and the serious direct damage they can cause (19). The soft scale, Ceroplastes rusci, was rarely found in vineyards. In previous studies, GLRaV-3 was detected in $C$. rusci and $P$. ficus individuals collected from Tunisian vineyards, but the ability of these insects to transmit the virus was not determined $(1,18)$. The widespread distribution of mealybug and soft scale insects in Tunisian vineyards justified an investigation to better understand their potential role in vectoring GLRaV-3 and GLRaV-5.

Transmission assays were therefore conducted to determine the ability of $P$. ficus and $C$. rusci to acquire and transmit local isolates of GLRaV-3 and GLRaV-5 from infected to healthy vines under experimental conditions.
MATERIALS AND METHODS

Transmission of GLRaV-3 and GLRaV-5 by mealybugs collected from naturally infected vines. To test the ability of Tunisian mealybugs (Planococcus spp.) to acquire and transmit leafroll viruses in vineyards, GLRaV-3 and GLRaV5 infected vines hosting mealybug colonies were identified in commercial vineyards by enzyme-linked immunosorbent assay (ELISA) with commercial kits (Bio-Rad, Hercules, CA, USA). Groups of five mealybugs of both juvenile and adult stages colonizing the infected vines were collected and tested for virus by ELISA. In addition, groups of 10 mealybugs were transferred from the infected vines onto 20 virus-free potted LN 33 (Couderc $1613 \times$ Thompson seedless) grapevines (Vitis vinifera) under greenhouse conditions and allowed access to the receptor vines for a period of 10 days to transmit the virus. In parallel experiments, mealybugs collected from ELISA-negative vines were transferred to virus-free vines to serve as negative controls, with two groups of five specimens tested for GLRaV-3 and GLRaV-5.

Conditions for transmission experiments in the greenhouse. The transmission trials were conducted during August and September in isolated compartments in a greenhouse at a temperature of $25 \pm 2^{\circ} \mathrm{C}$, under natural daylight conditions.

Virus sources and recipient grapevines. Canes of $V$. vinifera $\mathrm{cv}$. Italia approximately 30 to $40 \mathrm{~cm}$ in length and mixedly infected with GLRaV-3 and GLRaV-5 served as virus source plants. The plants were rooted and maintained in pots in the greenhouse under conditions similar to those for the transmission experiments. Virus-free receptors were rooted cuttings of LN33, which were maintained in a separate compartment in the greenhouse. The plants were regularly sprayed with insecticide (Chlorpyriphos) to ensure the absence of insects until they were used for controlled insect inoculations. Receptor and donor plants were tested by ELISA to make certain they were GLRaV-3 and -5 free and infected, respectively.

Establishing vector populations. $P$. $f$ icus mealybugs were initially reared on sprouted potatoes. Single females were isolated and allowed to reproduce, to as- 
sure genetic purity of the culture. Mealybug colonies derived from the single females were maintained and reared on sprouted potatoes for several generations under controlled conditions.

Colonies of $C$. rusci were reared and maintained immediately after collection on infected vines (cv. Italia) until virus transmission experiments were performed.

Experimental conditions for acquisition and transmission by $\boldsymbol{P}$. ficus. For virus acquisition, first and second instars of $P$. ficus, singly or together, were transferred from potatoes to GLRaV-3 and GLRaV-5 infected vines using leaves of Schinus molle as an attractant. Sessile adult females were transferred individually with fine brushes. After a 7-day acquisition access period (AAP) on infected sources, groups of five insects were tested by ELISA for the presence of GLRaV-3 and GLRaV-5. Mealybugs from potatoes and virus-free vines were used as negative controls. For virus transmission, mealybug specimens of each stage were transferred to healthy LN33 plants (10 to 15 specimens/plant) with leaf portions cut from infected vines, as described (13). Mature leaves colonized by mealybugs were used preferentially because of their higher virus level. All mealybugs were kept on receptor vines for an inoculation access period (IAP) of 10 days, after which vines were sprayed with the insecticide Chlorpyriphos.

Experimental conditions for acquisition and transmission by $C$. rusci. $C$. rusci was occasionally found in Tunisian vineyards. Individuals of this species were collected and maintained on GLRaV-3 and GLRaV-5 infected plants kept in a greenhouse. Fifteen groups of five first instars and 15 individual females were tested by ELISA for GLRaV-3 and GLRaV-5. For the transmission trials, the first instars were utilized since they represent the only mobile form. Transmissions were designed to enhance plant-to-plant contact to allow the first instars to move from infected to healthy vines. Insects reared on rooted cuttings of figs (Ficus carica) grown in pots in the greenhouse were used as negative controls.

Detection of GLRaV-3 and GLRaV-5 in insects and receptor plants. Mealybugs, scale insects, and grapevines were tested for GLRaV-3 and GLRaV-5 by double-antibody sandwich (DAS)-ELISA with commercial kits (Bio-Rad). Individual insects or pooled individuals were ground in a microcentrifuge tube with a plastic pestle in the presence of extraction buffer. After incubation with the antibody, the extract and the conjugate antibody were mixed and incubated overnight at $4^{\circ} \mathrm{C}$. Basal leaves of each vine used as a receptor plant were analyzed by DAS-ELISA for the presence of GLRaV-3 and GLRaV5 every 3 months for 12 months postinoculation. The results presented in this paper refer to the results obtained after 12 months. Absorbance values at $405 \mathrm{~nm}$ were recorded using an automatic microplate reader (Multiskan Ascent, Labsystems). Samples with absorbance readings equal to or exceeding three times that of the healthy control were considered positive for the presence of GLRaV-3 and GLRaV-5.

\section{RESULTS \\ Transmission of GLRaV-3 and GLRaV-5 by mealybugs collected from}

Table 1. Detection of Grapevine leafroll associated virus-3 (GLRaV-3) and Grapevine leafroll associated virus-5 (GLRaV-5) in Planococcus ficus or Ceroplastes rusci collected after acquisition feeding on infected vines of cv. Italia under controlled glasshouse conditions

\begin{tabular}{|c|c|c|c|c|}
\hline \multirow[b]{2}{*}{$\begin{array}{l}\text { Vector and } \\
\text { developmental stage }\end{array}$} & \multicolumn{4}{|c|}{ Virus detected in groups of five individuals } \\
\hline & $\begin{array}{l}\text { GLRaV-3 } \\
\text { only }\end{array}$ & $\begin{array}{l}\text { GLRaV-5 } \\
\text { only }\end{array}$ & $\begin{array}{l}\text { GLRaV-3 + } \\
\text { GLRaV-5 }\end{array}$ & $\begin{array}{l}\text { No virus } \\
\text { detected }\end{array}$ \\
\hline \multicolumn{5}{|l|}{ P. ficus } \\
\hline L1-L2 & $7 / 12$ & $1 / 12$ & $3 / 12$ & $1 / 12$ \\
\hline Adult females & $5 / 12$ & $1 / 12$ & $2 / 12$ & $4 / 12$ \\
\hline \multicolumn{5}{|l|}{ C. rusci } \\
\hline First instars & $0 / 15$ & $4 / 15$ & $3 / 15$ & $8 / 15$ \\
\hline Adult females & $0 / 15$ & $5 / 15$ & $4 / 15$ & $6 / 15$ \\
\hline
\end{tabular}

Table 2. Detection of Grapevine leafroll associated virus-3 (GLRaV-3) and Grapevine leafroll associated virus-5 (GLRaV-5) in vines of cv. LN33 12 months after transmission by Planococcus ficus or Ceroplastes rusci from virus-infected cv. Italia vines ${ }^{\mathrm{a}}$

\begin{tabular}{lcccc}
\hline \multirow{2}{*}{$\begin{array}{l}\text { Vector and } \\
\text { developmental stage }\end{array}$} & $\begin{array}{c}\text { GLRaV-3 } \\
\text { only }\end{array}$ & $\begin{array}{c}\text { GLRaV-5 } \\
\text { only }\end{array}$ & $\begin{array}{c}\text { GLRaV-3 + } \\
\text { GLRaV-5 }\end{array}$ & $\begin{array}{c}\text { No virus } \\
\text { detected }\end{array}$ \\
\hline \cline { 2 - 5 } P. ficus & $9 / 30$ & $2 / 30$ & $2 / 30$ & $17 / 30$ \\
$\quad$ L1-L2 & $2 / 30$ & $0 / 30$ & $1 / 30$ & $27 / 30$ \\
Adult females & $1 / 60$ & $0 / 60$ & $1 * / 60$ & $58 / 60$ \\
C. rusci & First instars & & & \\
\hline
\end{tabular}

a * Means this sample tested positive also to GLRaV-5, 18 months after transmission. naturally infected vines. GLRaV-3 and GLRaV-5 were detected by ELISA in extracts from 10 groups of five mealybugs (Planococcus spp.) collected in September from vines naturally infected with leafroll in the field. Five of 10 groups tested positive for GLRaV-3, 1 of 10 for GLRaV-5, and 2 of 10 for both GLRaV-3 and GLRaV-5. The concentration level of GLRaV-3 and GLRaV-5 in infected mealybugs was high enough for a clear-cut detection by ELISA when groups of five insects were analyzed. Twelve months after transmission with insects collected in September, ELISA indicated 1 of 20 recipient vines was infected with GLRaV-3 only, and 1 of 20 was infected with both GLRaV-3 and GLRaV-5.

Acquisition and transmission of GLRaV-3 and GLRaV-5 by $P$. ficus under controlled conditions. ELISA showed that both first and second instars and adult females of $P$. ficus acquired both GLRaV-3 and GLRaV-5 from infected vines of $\mathrm{cv}$. Italia (Table 1). GLRaV-3 only was detected in 7 of $12(58.3 \%)$ and 5 of 12 (41.7\%) groups of L1-L2 larvae and adult females, respectively. GLRaV-5 only was detected in 1 of $12(8.3 \%)$ groups of both L1-L2 larvae and adult females, while the viruses were detected together in 3 of 12 $(25 \%)$ and 2 of $12(16.7 \%)$ groups of L1L2 and adult females, respectively (Table 1). Based on test results at 12 months after inoculation, transmission of both viruses was higher when vines were inoculated with juvenile instars (Table 2). GLRaV-3 only was detected in 9 of $30(30 \%)$ and 2 of $30(6.7 \%)$ of canes inoculated with L1L2 instars and adult females, respectively. GLRaV-5 was detected singly only in 2 of $30(6.7 \%)$ canes inoculated by L1-L2 and in no canes inoculated by adult females. Both viruses were detected together in 2 of $30(6.7 \%)$ and 1 of 30 canes inoculated by the L1-L2 and adult females, respectively.

Acquisition and transmission of GLRaV-3 and GLRaV-5 by $C$. rusci under controlled conditions. $C$. rusc $i$ was able to acquire GLRaV-3 and GLRaV-5 from infected vines under experimental conditions, as indicated by ELISA detection in both first instars and in individual adult females. GLRaV-3 was not detected individually in first instars of C. rusci (Table 1). In contrast, GLRaV-5 was detected in 4 of $15(26.7 \%)$ and 5 of $15(33.3 \%)$ groups of five first instars and individual adult females, respectively, and both viruses were detected together in 3 of 15 (20\%) and 4 of $15(26.7 \%)$ groups of five instars and individual adult females, respectively. It is interesting to note that GLRaV-3 was always detected in a mixture with GLRaV-5 (7 of 30 samples tested), whereas GLRaV-5 was detected singly in nine samples.

In transmission experiments to cv. LN33 vines with $C$. rusci first instars, at 12 months after inoculation, out of 60 vines 
tested, GLRaV-3 was detected in one vine singly $(1.7 \%)$ and in one vine in a mixed infection with GLRaV-5, whereas GLRaV5 was not detected in any of the 60 recipient vines (Table 2). At 18 months, one of the GLRaV-3 infected vines also tested positive for GLRaV-5 (Table 2).

\section{DISCUSSION}

$P$. ficus and $P$. citri were the predominant species of mealybugs in Tunisian vineyards, while $C$. rusci was found occasionally (N. Mahfoudhi and M. H. Dhouibi, unpublished data). In the present study, both $P$. ficus and $C$. rusci were able to acquire local isolates of GLRaV-3 and GLRaV-5 from infected vines and transmit them to healthy vines under experimental conditions. $P$. ficus easily acquired GLRaV-3 and GLRaV-5 with an incidence that reached mean values (considering both juvenile and adult stages) of 70.8 and $29.2 \%$, respectively. Comparing developmental stages of $P$. ficus, GLRaV-3 was detected in $83.3 \%$ of groups of juvenile instars compared to $58.3 \%$ of adult females.

The same two viruses were transmitted with success to healthy vines with rates of 23.3 and $8.3 \%$, respectively. In particular, the results obtained in these experiments suggest that $P$. ficus is more efficient in the transmission of GLRaV-3 than of GLRaV5 , possibly explaining the higher incidence of GLRaV-3 in vineyards (76.3\%), compared with GLRaV-5 (38.5\%) (20). A similar difference in the efficiency of transmission of GLRaV-3 and GLRaV-5 was also observed for Pseudococcus longispinus (13). Similar to acquisition of the virus, the juvenile stages seem to be more effective in transmission of the virus than are the adult females (36.7\% versus $10 \%)$.

Since the same behavior was observed for GLRaV-5, these observations suggest that the first and second instars of $P$. ficus are more efficient than adult females in the transmission of these viruses. The lower efficiency in the transmission of grapevine ampeloviruses by mature mealybugs agrees with previous data that demonstrated that the first instars of both Pseudococcus longispinus and Pseudococcus calceolariae were efficient vectors of GLRaV-3 (26). Similarly, observations of decreased vector efficiency of older adult female mealybugs have been made for viruses infecting other crops (27).

The higher efficiency of transmission of GLRaV-3 and GLRaV-5 by juvenile instars represents a further complicating factor in the epidemiology of these two viruses in a viticultural setting, because of their easier dispersion by wind over considerable distances (30). In particular, serious consideration must be given to this aspect when establishing isolation conditions for mother plant plots devoted to production of certified, virus-free propagation material. The results of this study confirm the previously reported ability of $P$. ficus to transmit GLRaV-3 $(11,10,32)$, and demonstrate for the first time the capacity of the same species to transmit GLRaV-5.

The coccid $C$. rusci was found only occasionally in vineyards, and both first instars and adult females acquired GLRaV-3 only with GLRaV-5, with neither developmental stage acquiring GLRaV-3 singly. Although the acquisition efficiency of adult females was high, the low transmission efficiency may have no epidemiological importance in the transmission of the two viruses despite the permanent presence of this coccid species in vineyards. Of greater importance is the potential vectoring role of the first instars of C. rusci, which represent the only mobile forms of this insect for dissemination from one plant to another. Similar to adult females, despite the apparent high level of acquisition of GLRaV-3 and GLRaV-5 (20 and $46.7 \%$, respectively) by juvenile forms tested, the observed transmission of these two viruses by $C$. rusci juveniles was very low, at 3.3 and $1.7 \%$ for GLRaV-3 and GLRaV-5, respectively. This low level of transmission may be due to an intrinsic characteristic of the vector or more possibly to the limited movement of the insects from infected to healthy vines observed under our experimental conditions. Nevertheless, $C$. rusci can be considered as a new potential vector species for GLRaV-3 and GLRaV-5; however, its role in the natural spread in vineyards may be very limited, unless high levels of infestation occur. In such cases, measures should be taken to limit its spread in vineyards.

This study corroborates earlier research on the capacity of soft scale coccids to transmit GLRaV-3 $(3,28)$. High population densities are not necessarily required for virus transmission (6), and this can explain some of the cases where natural spread of GLRaV-3 occurred but no vector was identified $(9,15)$. Although further experimental confirmation is needed, indigenous Tunisian populations of $P$. ficus and $C$. rusci are apparently able, with different efficiency rates, to transmit local isolates of GLRaV-3 and GLRaV-5. This transmission ability and the high incidence of leafroll-associated viruses in Tunisian vineyards make the control of leafroll epidemics more complicated, even with the implementation of certification programs. Further studies are needed to better understand the activity of vectors in the spread of the disease in vineyards. In addition to the use of virus-free propagation material, an integrated approach to mealybug control is highly recommended to prevent field spread of leafroll disease.

\section{LITERATURE CITED}

1. Acheche, H., Fattouch, S., Mhirsi, S., Chabbouh, N., Marzouki, N., and Marrakchi, M. 2000. Studies on grapevine leafroll associated virus 3 transmission by mealybugs in Tunisian grapevines. Page 23 in: Proc. Int. Counc.
Study Viruses Virus-like Dis. Grapevine, 13th. University of Adelaide and CSIRO.

2. Alkowni, R., Rowhani, A., Daubert, S., and Golino, D. 2004. Partial characterization of new Ampelovirus associated with grapevine leafroll disease. J. Plant Pathol. 86(2):123-133.

3. Belli, G., Fortusini, A., Casati, P., Belli, L., Bianco, P., and Prati, S. 1994. Transmission of grapevine leafroll-associated closterovirus by the scale insect Pulvinaria vitis L. Riv. Patol. Veg. S.V. 4:105-108.

4. Belli, G., Fortusini, A., and Prati, S. 1993 Natural spread of grapevine leafroll disease in a vineyard of northern Italy. Page 110 in: Proc. Int. Counc. Study Viruses Virus-like Dis. Grapevine, 11th. Montreux, Switzerland.

5. Boulila, M., Chabbouh, N., Cherif, C., and Martelli, G. P. 1991. Current knowledge on virus and virus like-diseases of grapevine in Tunisia. Pages 104-110 in: Proc. Int. Counc. Study Viruses Virus-like Dis. Grapevine, 10th. Volos, Greece.

6. Cabaleiro, C., and Segura, A. 1997. Field transmission of grapevine leafroll associated virus 3 (GLRaV-3) by the mealybug Planococcus citri. Plant Dis. 81:283-287.

7. Cabaleiro, C., and Segura, A. 1997. Some characteristics of the transmission of grapevine leafroll associated virus 3 by Planococcus citri Risso. Eur. J. Plant Pathol. 103:373-378.

8. Cabaleiro, C., and Segura, A. 2006. Temporal analysis of grapevine leafroll associated virus 3 epidemics. Eur. J. Plant Pathol. 114:441-446.

9. Dimitrijevic, D. 1973. Some observations on natural spread of grapevine leafroll disease in Yugoslavia. Riv. Patol. Veg. 9:114-119.

10. Douglas, N., and Krüger, K. 2006. Grapevine leafroll-associated virus 3 transmission efficiency of Planococcus ficus and Pseudococcus longispinus (Hemiptera: Pseudococcidae) Pages 191-192 in: Proc. Int. Counc. Study Viruses Virus-like Dis. Grapevine, 15th. Stellenbosch, South Africa.

11. Engelbrecht, D. J., and Kasdorf, G. G. F. 1990. Transmission of grapevine leafroll disease and associated clostero-viruses by the vine mealybug, Planococcus ficus. Phytophylactica 22:341-346.

12. Fortusini, A., Scattini, G., Prati, S., Cinquanta, S., and Belli, G. 1997. Transmission of grapevine leafroll virus 1 (GLRaV-1) and grapevine virus A (GVA) by scale insects. Pages 121-122 in: Proc. Int. Counc. Study Viruses Virus-like Dis.f Grapevine, 12th. Lisbon, Portugal.

13. Golino, D. A., Sim, S. T., Gill, R., and Rowhani, A. 2002. California mealybugs can spread grapevine leafroll disease. Calif. Agric. 56:196-201.

14. Gugerli, P. 2003. Grapevine leafroll and related viruses. Pages 25-31 in: Proc. Int. Counc. Study Viruses Virus-like Dis. Grapevine, 14th University of Bari, Locorotondo, Italy.

15. Habili, N., Fazeli, C. F., Ewart, A., Hamilton, R., Cirami, R., Saldarelli, P., Minafra, A., and Rezaian, M. A. 1995. Natural spread and molecular analysis of grapevine leafrollassociated virus 3 in Australia. Phytopathology 85:1418-1422.

16. Jordan, D., Petersen, C., Morgan, L., and Segaran, A. 1993. Spread of grapevine leafroll and its associated virus in New Zealand vineyards. Pages 113-114 in: Proc. Int. Counc. Study Viruses Virus-like Dis. Grapevine, 11th. Montreux, Switzerland.

17. Kovacs, L. G., Hanami, H., Fortenberry, M., and Kaps, M. L. 2001. Latent infection by leafroll agent GLRaV-3 is linked to lower fruit quality in French-American hybrid grapevines Vidan blanc and St. Vincent. Am. J. Enol. Vitic. 52(3):254-259.

18. La Notte, P., Buzkan, N., Choueiri, E., Minafra, A., and Martelli, G. P. 1997. Acquisition and transmission of grapevine virus $\mathrm{A}$ by the mealybug Pseudococcus longispinus. J. Plant 
Pathol. 79:79-85.

19. Mahfoudhi, N., Dhouibi, M. H., and Chabbouh, N. 2005. Etude de quelques paramètres morphologiques et biologiques de la cochenille farineuse Planococcus citri (Risso) (Homoptera: Pseudococcidae). Rev. INAT 20(2):51-63.

20. Mahfoudhi, N., Digiaro, M., and Dhouibi, M. H. 2008. Incidence and distribution of grapevine leafroll-associated viruses in Tunisian vineyards. J. Phytopathol. 156:556-558.

21. Mahfoudhi, N., Digiaro, M., Savino, V., and Di Terlizzi, B. 1998. Pages 197-204 in: Viruses and virus diseases of grapevine in Tunisia. OEPP/EPPO Bull. 28.

22. Mahfoudhi, N., Habili, N., Masri, S. A., and Dhouibi, M. H. 2007. First report on the occurrence of Grapevine leafroll-associated viruses 5 and 9 in Tunisian grapevines. Plant Dis. 91:1359.

23. Martelli, G. P. 1993. Leafroll. Pages 37-44 in: Graft transmissible diseases of grapevines. Handbook for detection and diagnosis. FAO Rome, 1993, 37-44.

24. Martelli, G. P., Agronovsky, A. A., Bar-Joseph,
M., Boscia, D., Candresse, T., Coutts, R. H. A., Dolja, V. V., Falk, B. W., Gonsalves, D., Jelkman, W., Karasev, A. V., Minafra, A., Namba, S., Vatten, H. J., Wisler, G. C., and Yoshikawa, N. 2002. Virology division news: The family Closteroviridae revised. Arch. Virol. 147:20392044.

25. Nakano, M., Nakaune, R., and Komazaki, S. 2003. Mealybug transmission of grapevine viruses in Japan. Page 218 in: Proc. Int. Counc. Study Viruses Virus-like Dis. Grapevine, 14th. University of Bari, Locorotondo, Italy.

26. Petersen, C., and Charles, J. 1997. Transmission of grapevine leafroll-associated closteroviruses by Pseodococcus longispinus and Pseudococcus calceolariae. Plant Pathol. 46:509-515.

27. Sether, D. M., Ullman, D. E., and Hu, J. S. 1998. Transmission of pineapple mealybug wilt-associated virus by two species of mealybug (Dysmicoccus spp.). Phytopathology 88:1224-1230.

28. Sforza, R., Boudon-Padieu, E., and Greif, C. 2003. New mealybug species vectoring Grape- vine leafroll-associated viruses-1 and -3 (GLRaV-1 and -3). Eur. J. Plant Pathol. 109:975-981.

29. Sim, S. T., Rowhani, A., and Golino, D. A 2003. Experimental transmission of grapevine leafroll-associated virus 5 and 9 by longtailed mealybugs. Pages 211-212 in: Proc. Int Counc. Study Viruses Virus-like Dis. Grapevine, 14th. University of Bari, Locorotondo, Italy.

30. Walker, J. T. S., Charles, J. G., Froud, K. J. and Connolly, P. 2004. Leafroll virus in vineyards: Modelling the spread and economic impact. Report to New Zealand winegrowers limited. Hortic. Res. Client Rep. $\mathrm{N}^{\circ} .12795$.

31. Woodham, R. C., Antcliff, A. J., Krake, L. R., and Taylor, R. H. 1984. Yield differences between sultane clones related to virus status and genetic factors. Vitis 23:73-83.

32. Zorloni, A., Prati, S., Bianco, P. A., and Belli, G. 2004. Further data on the experimental transmission of grapevine leafroll-associated virus 1 and 3 and of grapevine virus A by mealybugs. J. Plant Pathol. 86:339-340. 